\title{
Single cell protein (SCP) production and potential substrates: A comprehensive review
}

\author{
Abdur Raziq ${ }^{1}$, Muhammad Lateef ${ }^{2}$, Asad Ullah $^{3}$, Hayat Ullah ${ }^{1 *}$ and \\ Muhammad Waseem Khan ${ }^{4}$ \\ 1. Department of Bioinformatics \& Biotechnology, Faculty of Life Science, Government College University \\ Faisalabad-Pakistan \\ 2. Biotechnology Department of Center for Agricultural Biochemistry \& Biotechnology Faculty of Agriculture, \\ University of Agriculture, Faisalabad-Pakistan \\ 3. Department of Microbiology, Faculty of Life Science, Balochistan University of Information Technology, \\ Engineering and Management Sciences (BUITEMS) Quetta-Pakistan \\ 4. Department of Biotechnology, Balochistan University of Information Technology Engineering and Management \\ Sciences, Quetta-Pakistan \\ *Corresponding author's email: hayatullah22@gcuf.edu.pk \\ Citation \\ Abdur Raziq, Muhammad Lateef, Asad Ullah, Hayat Ullah and Muhammad Waseem Khan. Single cell protein \\ (SCP) production and potential substrates: A comprehensive review. Pure and Applied Biology. Vol. 9, Issue 3, \\ pp1743-1754. http://dx.doi.org/10.19045/bspab.2020.90185
}

\begin{tabular}{llll}
\hline Received: 02/01/2020 & Revised: 22/03/2020 & Accepted: 05/04/2020 & Online First: 13/04/2020 \\
\hline \hline
\end{tabular}

\section{Abstract}

Single cell proteins (SCP) are the edible dead, dry cells of micro-organisms that can be used as protein source in human food and animal feed, either as whole living cell or in dried form. Microbial species of yeast, fungi and bacteria that are Generally Recognized As Safe (GRAS), can be used as a source of single cell protein. Inexpensive microbial growth culture components can be utilized as source of carbon and energy to grow these microorganisms as biomass, amino acids or protein source. Besides being used as food or feed supplement, single cell protein strains have diverse range of properties, as it can eradicate pathogenic microorganism from human or animal gut either by competition with available nutrient sources or by producing enzymes or metabolites with antimicrobial activities. Due to increase in population around the globe, the global demand for high-quality protein rich foods have increased. Novel approaches for alternative sources are needed to meet the global challenges. SCP strains with capacity to produce cell wall degrading enzymes and metabolites with antimicrobial activity can play a major role to meet the global food demand. Poultry farming of broiler and layer is already playing an important role to meet the need of protein in the developing world. However, high nucleic acid content, un-digestible cell wall, unacceptable flavors and colors and high contamination rate are the certain limitations that need further attention.

Keywords: Conventional and unconventional substrate; Fermentation; Food production;

Malnutrition; Single cell protein

\section{Introduction}

The rapid increase in the world population has increased the demand of necessary food items at a rapid pace. Particularly, protein source deficiency has become a serious problem for human beings [1]. Efforts have been made for production of unconventional and alternate sources of protein. Since 1996, 
new sources from microorganisms (yeast, bacteria, algae and fungi) were used as protein biomass [2, 3]. In 1968, Massachusetts Institute of Technology (MIT) professor Carol Wilson coined the term 'Single Cell Protein (SCP)' instead of petroprotein and microbial protein. In those days, some people disliked the use of microorganisms in food additives, despite that SCP idea was innovative to meet global food problems [4].

World suffers from malnutrition particularly under developed and developing countries where rapid increase in population has increased the demand for protein and nutrients. Malnutrition is a serious problem for these resource poor countries and if not tackled in a proper way, may lead to major crises. Therefore, the production of single cell proteins are promising way to tackle protein deficiency problem worldwide [5].

Single cell proteins (SCPs) or microbial proteins are the dead dried cells of microorganisms or purified protein isolated from microorganism's cell culture and used as a food supplement to humans' food as vitamin carriers, aroma carriers, emulsifying aids and in animals feed as fattening poultry, calves, pigs, and fish [6]. It also has applications in leather and paper industry [7]. SCPs have high protein content (60-80\% as dry cell weight), also contains carbohydrates, lipids, vitamins, nucleic acids and minerals. It has high quantity of essential amino acid like methionine and lysine. Conventional substrate (starch, fruit, molasses and fruit waste) and unconventional substrate (petroleum by products, ethanol, natural gas, lignocellulosic biomass and methanol) have been used for SCPs production [2]. Interest in the production of proteins from microbes for animal fodder depends on production cost in comparison to the market price competitors, like fishmeal and soya protein. These microbes have capability to utilize waste and cheap feedstock to produce biomass, rich in protein and amino acids.

There are some interesting characteristics for the production of single cell proteins. It utilizes waste or raw materials and microorganisms on large scale, convert substrate with high efficiency, increasing microbial growth that results in good productivity. Also, seasonal factors have no effect on effectiveness of process [5]. SCP products contain high quantity of nucleic acid (6-10\%) that increase uric acid level in serum. This access in quantity results precipitation of uric acid which can cause health problems i.e. formation of gout and kidney stone. The recommended dose of SCP supplemented to human diet should have nucleic acid contents below $2 \%$ [8].

SCPs are used in animal diet and fattening calves, pigs, broilers, as laying hens feed, fish breeding and feeding of pet. It is also used in foodstuffs as emulsifying agent, carrier of vitamins and scent, in soups, baked items as nutritional supplement, readymade meals and food recipes and have also applications in leather and paper processing and in foam stabilizing agent industry [5]. Medicinal uses of Spirulina enhances antiviral and anticancer activity, improve and strengthen immune system. Studies indicated that use of Spirulina up to 4 weeks decrease serum cholesterol level due to high quantity of gamma linolenic acid present in cyanobacteria. SCP production is a good way to overcome environmental pollution by utilizing waste materials. It is an efficient tool to transform agricultural waste such as rice hulls, rice straw, starchy residues and manure as a substrate into useful products [9].

Naturally, microorganisms live symbiotically with each other and some species are more efficient when they have interaction with other microbes. Same is in case of co-culture, where mix culture fermentation contains more than one microorganism mostly used for production of enzymes, antibiotics, 
various types of fermented foods, dairy fermentation, composting and SCP production. Co-culture production is more efficient than mono-culture production as it improves substrate utilization, increase their productivity, adaptability to conditions and decrease risk of contamination. Co-culture results through synergic interaction may overcome nutritional limitations. In synergic interaction the enzyme product of one microbe is used as substrate for other microorganisms $[\mathbf{1 0}, \mathbf{1 1}]$.

\section{Microorganisms for single cell protein (SCP) production}

\section{Single cell protein (SCP)-Yeast}

Yeast is a good source of SCP, used from long time. In Germany during First World War, Torula yeast (candida utilis) were used in sausages and soups. Nowadays, it is frequently used in animal feed as food supplements (dog and fish feed) and used as seasoning food in vegetarian diet. Yeast cell is larger than bacterial cell, can easily harvest, have high lysine and malic acid contents and low nucleic acid contents. Yeast cells have capability to grow on acidic $\mathrm{pH}$. Yeast have low growth rate, low methionine and protein content (45-65\%) as compared to bacteria. Yeast is also a good source for SCP production due to its superior nutritional quality. A variety of substrate and microbes are used for SCP production but necessary factor to consider before use of SCP is to check the toxic and carcinogenic compounds, produced by microbe or by substrate and synthesized during production process. Two main limiting factors of yeast are high nucleic acid contents and low cell wall digestibility $[4,12]$.

\section{Single cell protein (SCP)-Bacteria}

Many bacterial species have been under investigation for production of SCPs. Methylotrophic bacterium Methylophilus methylotrophus have about 2 hours generation time and used in animal feed, produce good protein composition than other microbes. The characteristics of bacteria that make it suitable for SCP production include their short generation time and rapid growth with high protein content (50-80\%) (Table 1). Photosynthetic Purple Non-Sulphur Bacteria (PNSB) contains $70-72 \%$ protein, highly resistant to toxicants and their protein compositions of necessary amino acids are similar to soybean protein. Its biomass is very useful in fish feed and rich in protein [13]. Ammonia, urea, ammonium salts, organic nitrogen and nitrates in wastes are good source of nitrogen for bacteria and have capability to grow on different raw materials. Bacteria have high nucleic acid contents while less quantity of sulphur containing amino acids. The culture of bacteria has high risk of contamination and cell recovery is difficult. Bacterial culture medium requires mineral nutrient supplement to furnish nutrients $[7,14]$. The selection of microbial strain for production of SCPs are based on the following criteria:

- Heat generation, oxygen requirements during fermentation process and foam character,

- Performance like growth rate, yield, heat and $\mathrm{pH}$ tolerance,

- Genetic stability during fermentation process and growth morphology,

- Their end product composition and structure in term of protein,

- Have easy recovery and purification of their yield [9].

Bacteria have small cell size and low density, difficult to harvest in fermented medium, have high nucleic acid contents, and general perception of public that bacteria are harmful, awareness required to remove misconception about bacterial protein [14]. 
Table 1. Bacterial protein content as single cell protein (SCP) on specific substrates

\begin{tabular}{|c|c|c|c|}
\hline Bacteria & Substrate & $\begin{array}{c}\text { Protein } \\
\text { content }(\boldsymbol{\%})\end{array}$ & References \\
\hline Haloarcula sp. IRU1 & Petrochemical wastewater & 76 & {$[\mathbf{1 5}]$} \\
\hline $\begin{array}{c}\text { Methylococcus capsulatus, } \\
\text { Ralstonia } \text { sp., Brevibacillus agri, } \\
\text { Aneurinibacillus sp. }\end{array}$ & Methane (Natural gas) & $67-73$ & {$[\mathbf{1 6}]$} \\
\hline Bacillus subtilis & Ram horn & 71 & {$[\mathbf{1 7}]$} \\
\hline Methylomonas sp. & Methane salt broth & 69 & {$[\mathbf{1 8}]$} \\
\hline Bacillus cereus & Ram horn & 68 & {$[\mathbf{1 7}]$} \\
\hline Escherichia coli & Ram horn & 66 & {$[19]$} \\
\hline Rhodopseudomonas palustris & Latex rubber sheet wastewater & $55-65$ & {$[\mathbf{2 0}]$} \\
\hline Corynebacterium ammoniagenes & Glucose + Fructose & 61 & {$[\mathbf{2 1}]$} \\
\hline $\begin{array}{c}\text { Rhizospheric diazotrophs } \text { (whole } \\
\text { microbial community) }\end{array}$ & Brewery wastewater & $>55$ & {$[\mathbf{2 2}]$} \\
\hline Bacillus pumilis & Potato starch processing waste & 46 & {$[\mathbf{2 3}]$} \\
\hline Cupriavidus necator & Synthetic growth medium & $40-46$ & {$[\mathbf{2 4}]$} \\
\hline Bacillus licheniformis & Potato starch processing waste & 38 & {$[\mathbf{2 5}]$} \\
\hline Bacillus subtilis & Soybean hull & 12 & \\
\hline
\end{tabular}

\section{Single cell protein (SCP)-Algae}

In East Asia and Central Africa, algae have been used as part of their diet. Algae (Chloralla, Coelastrum, Soenedesmus and Spirulina) have been found good for mass cultivation and utilization. Algae are easy in cultivation, have fast growth, have high nutrient and protein contents and good utilization of solar energy [4]. Microalgae are unicellular, photosynthetic found in sea, good choice for SCPs production due to their rapid growth rate, simple and inexpensive procedures to utilize microalgae. Nutritional and comprehensive analysis demonstrated that microalgae have capability to produce high quality protein through SCP procedures [26]. Spirulina cultivation is easier than algal because no aeration required for this specie and it utilize maximum amount of carbon. In tropical countries, Spirulina is cultured under heterotrophic, autotrophic and mixotrophic conditions. But algae concentrate with heavy metals have cellulosic cell wall which are undigestible by humans [14].

\section{Single cell protein (SCP)-Filamentous Fungi}

In 1973, during second international conference at MIT, it was reported that some filamentous fungi and actinomycetes can produce proteins from different substrates. Attempts were made during World War II to culture Rhizopus and Fusarium grown and used as protein food. The inoculum of Rhizopus arrhizus were chosen because of its nontoxic nature. The complex compound saprophytic fungi were grown to convert into simple form for the production of high amount of fungi biomass. The yield of mycelia depends on substrate and organism. The optimum condition for SCP production using Aspergillus niger, glucose concentration are the most effective factor as compared to $\mathrm{pH}$ of medium and potassium hydrogen phosphate concentration [27]. Some strain of molds (A. fumigatus Fusarium graminearum, Aspergillus niger) are hazardous to animals and humans therefore, toxicological evaluations must be done before for the selection of the strains for production of SCPs. While fungus that have 
been used are Fusarium graminearum, Chaetomium celluloliticum, Aspergillus fumigates, Penicillium cyclopium, Rhizopuschinensis, Cephalosporium cichorniae, Scytalidum aciduphlium, A. niger, A.oryzae, Tricoderma viridae, and
Tricoderma alba Paecilomyces varioti [2]. Some important species are included in (Table 2). Filamentous fungi are easy to harvest while have low growth rate, protein content and accessibility [4].

Table 2. Fungal protein content as single cell protein (SCP) produced from specific substrates

\begin{tabular}{|c|c|c|c|}
\hline Organism & Substrate & $\begin{array}{c}\text { Protein } \\
\text { content }(\%)\end{array}$ & References \\
\hline Unspecified, marine yeast & Prawn shell wastes & $61-70$ & {$[28]$} \\
\hline Pleurotus florida & Wheat straw & 63 & [29] \\
\hline Kluyveromyces marxianus & $\begin{array}{l}\text { Orange pulp, molasses, brewer's } \\
\text { spent grain, whey, potato pulp }\end{array}$ & 59 & {$[30]$} \\
\hline Candida tropicalis & Molasses & 56 & {$[31]$} \\
\hline Kefir sp. & Cheese whey & 54 & [32] \\
\hline Yarrowia lipolytica & $\begin{array}{l}\text { Inulin, crude oil, glycerol waste } \\
\text { hydrocarbons }\end{array}$ & $48-54$ & {$[33,34]$} \\
\hline Aspergillus niger & Waste liquor & 50 & [35] \\
\hline Aspergillus niger & Stick water & 49 & [36] \\
\hline Hanseniaspora uvarum & Spoiled date palm fruits & 49 & [37] \\
\hline Candida crusei & Cheese whey & 48 & [38] \\
\hline Candida utilis & $\begin{array}{l}\text { Poultry litter; waste capsicum } \\
\text { powder }\end{array}$ & $\begin{array}{l}29 \\
48\end{array}$ & [39] \\
\hline Candida utilis & Potato starch industry waste & 46 & [22] \\
\hline Fusarium venenatum & Glucose (Product: Quorn ${ }^{\mathrm{TM}}$ ) & 44 & [40] \\
\hline Kluyveromyces marxianus & Cheese whey & 43 & [41] \\
\hline Chrysonilia sitophilia & Lignin & 39 & [42] \\
\hline Aspergillus niger & Potato starch processing waste & 38 & [24] \\
\hline Trichoderma harzianum & Cheese whey filtrate & 34 & {$[43]$} \\
\hline Trichoderma virideae & Citrus pulp & 32 & [44] \\
\hline Debaryomyces hansenii & $\begin{array}{c}\text { Brewery's spent grains } \\
\text { hemicellulosic hydrolysate }\end{array}$ & 32 & [44] \\
\hline Candida tropicalis & Bagasse & 31 & [45] \\
\hline Aspergillus ochraceus & Rice bran & 10 & [46] \\
\hline Aspergillus oryzae & Rice bran (de oiled) & 24 & [47] \\
\hline Saccharomyces cerevisiae & $\begin{array}{l}\text { Orange pulp, molasses, brewer's } \\
\text { spent grain }\end{array}$ & 24 & [30] \\
\hline Aspergillus niger & Banana wastes & 18 & [48] \\
\hline Aspergillus niger & Apple pomace & $17-20$ & [49] \\
\hline Aspergillus niger & Rice bran & 11 & \multirow{4}{*}{ [46] } \\
\hline Aspergillus flavus & \multirow{3}{*}{ Rice bran } & \multirow{3}{*}{10} & \\
\hline $\begin{array}{l}\text { Fusarium semitectum and spl } \\
\text { and sp2 }\end{array}$ & & & \\
\hline Cladosporium cladosporioides & & & \\
\hline
\end{tabular}




\section{Production of single cell protein (SCP)}

Single cell protein can be grown on industrial waste materials (agricultural waste, beverages waste, hydrocarbons, food processing waste and animal and human excreta) as substrate. Production process of SCPs from any microbe and substrate are the carbon source provision that may require chemical or physical pre-treatments. Addition of carbon, phosphorus, nitrogen and other nutrients are required for optimum growth of selected microbe. Maintaining hygienic or sterile condition to prevent the medium from contamination require complete setup. The inoculation of selected microbe onto the medium require adequate aeration for SCP process except if Algae are the desired microbes. Microorganisms biomass recover from medium and their processing is good for its storability [4].

Single cell protein (SCP) production process

Microbial screening for SCPs production based on the current literature include mutagenesis and other genetic techniques. Efficient microorganism strains obtained from various habitats i.e. water, soil, air and others have capability to produce good amount of protein. Monosaccharides and disaccharides containing carbon source are most preferable substrates for production of SCPs that contain carbon, phosphorus, nitrogen supplements, have high production yield in short time period. There are three categories of substrates used for production of SCPs including renewable plant resources such as starch, sugar, cellulose; High energy resources such as gas-oil, natural gas, ethanol, methanol n-alkanes and acetic acid; and various wastes such as sulfite waste liquor, molasses, whey, milk and fruit wastes. Before cultivation, technical conditions for the desired strain and their cell structure with all metabolic pathways will be determined for technology development, adoption of technical performance of the reaction process in order to make the production ready for large technical scale utilization [9]. Economic factors involved for the production on large scale include energy consumption and cost production which need to be analyzed thoroughly. In case of SCPs produced for human consumption and used in animal feed; safety of product is necessary to be tested as some microbes produce toxins during process and need proper monitoring $[9,50]$.

\section{Fermentation strategies}

For production of SCPs the desired strain undergoes through fermentation process, divide through utilizing substrate as carbon source and culture mass is isolated through separation process. Cultivation process starts from microbial screening, in which microbial strains are obtained from soil, air, water; and all pathways and cultivation conditions are determined. Environmental protection and safety demands are considered related to process and yield. Fermentation different types are as follows:

\section{Submerged fermentation}

In submerged fermentation process, substrate always remains in liquid form that contains necessary nutrients required for microbial growth during fermentation process. The fermenter operates substrate continuously and the product harvested regularly from fermenter through different techniques, the product is centrifuges or filtered and stored in dry form. Cultivation process require aeration due to generation of heat during process which is remove through cooling device. Microbial biomass separated through different methods, as single cell protein such as filamentous fungi separated through filtration and yeast and bacteria separated through centrifugation.

\section{Semisolid fermentation}

In semisolid fermentation process, the substrate is mostly used in solid state. Cultivation process consist of many operations such as stirring and mixing of 
multiphase system, transport of oxygen and removal of heat to surroundings. U-loop fermenter is a bioreactor specially designed for identifying mass and heat transportation. A suitable medium and carbon source, prevention of medium from contamination and isolation of end product are key steps of preparation of medium for SCP production. Carbon source may be Methanol, ethanol, gaseous hydrocarbons, n-alkanes, carbon oxide, polysaccharides or molasses.

\section{Solid state fermentation}

Solid state fermentation process consists of deposition of a solid substrate such as wheat bran or rice on flatbeds after seedling with microbes and left the substrate in temperature control room for few days. Liquid state fermentation process is done in tanks at industrial scale [2].

\section{Potential substrates for single cell protein (SCP) production}

The substrate used for production of single cell proteins should be nontoxic, non-exotic, renewable, cheap and non-seasonal [9]. There is various type of substrates for production of SCP. The researchers urge to form very high quality protein from low grade waste material with the help of microbes [51]. Carbohydrates most commonly used substrate for single cell production, due to its renewable character [52]. There are many other substrates for production of $\mathrm{SCP}$, conventional substrates include fruit, molasses, starch and vegetable waste while unconventional substrates are natural gas, methanol, ethanol, petroleum by products, and lignocellulosic biomass [53]. Major factors determined for SCP production are substrate availability and proximity to the production plant. Other substrates include leaf juice, lignocellulosic agricultural waste, soybean hull, starch and sugar processing waste, fruit waste (fiber rich), poultry waste, spent grains, pawn shell waste, protein or lipid rich sources, wastewaters (protein rich), waste capsicum powder, slaughterhouse waste, soybean meal and combined agricultural wastes [54].

\section{Molasses}

Molasses are the by-product of concentrated sugar solution sugar cane and sugar beet left after crystallization of sugar. It is rich source of sugars $45-55 \%$ such as melibiose, raffinose, fructose, glucose and sucrose, nitrogen compounds $10 \%$, minerals and fat $10 \%$ [31]. It is easy for cultivation of microbes [55]. Its usage for production of SCP depends upon their price, availability, and composition of molasses [56].

\section{Dairy waste}

Whey and other dairy wastes contains high levels of biological oxygen demand (BOD) and chemical oxygen demand (COD), have high quantity of fate, oils, phosphorus and nitrogen compounds [57], without prior treatment such compounds can cause ecological issues if not tackle properly. Dairy waste can have high quantity of either protein or lactose, that depends upon milk processing technology [56].

\section{Fruit waste (simple sugar rich)}

Fruit waste main mass depends upon fruit type and part of fruit. Whole fruit waste has high quantity of carbohydrates and is rich in nutrition required for microbial growth. While parts of fruit such as lady finger and banana only $5-30 \%$ are harvested. If fruit wastes consists of inner and outer shells, seeds and peels remains during juice processing have high fiber and polysaccharides [56].

\section{Starch rich sources and bran}

Tuber and grains residues have high quantity of starch, but it is required to be hydrolyzed to monosaccharides before use [58]. Bran is a by-product obtained after grains processing, for oil extraction used as food additive and animal feed. Bran contain high quantity of starch, protein, fiber and also good source of iron, lipids, vitamin B, phytosterol, antioxidants and phenolic acid [56]. 


\section{Soybean meal}

Soybean meal remains after oil extraction from soybean, have high quantity of protein, carbohydrates, fat and minerals are most widely used in animal feed [59].

Starch is the most abundant carbohydrate obtained from maize, cereals and rice. For SCP production starch is preferable substrate due to its low cost. Whey is the remaining liquid left after extraction of fat and protein from milk. Whey can be obtained from curdling process or after ultrafiltration process for production of cheese. Whey is a good source for SCP production but due to seasonal supply and high-water content the transport may be costly.

\section{Methanol}

Methanol (natural gas) is good substrate for SCP production due to its volatility, selectivity and non-toxic nature despite of having low solubility, non-high purity and low flammability as Imperial Chemical (ICI) used methanol as substrate for single cell protein production and ammonia gas in place of nitrogen source. Cellulose considered as potential substrate for SCP production but it need pre-treatment before use [60].

\section{Dates waste}

Dates are produced in high quantity in southwest and western Asia. Dates have 60$70 \%$ sugar and frequently used in fermentation. Dates by-product is date syrup which look like dark dense fluid, contain important nutrients required for microbial growth. Date syrup is used as carbon source for SCP production [61].

SCP production using agricultural wastes For production of high-quality protein, agricultural waste is the most useful, cheap material which is easily obtained. SCP produced from agricultural waste have high nutritional quality, used as supplement in food and feed agricultural waste include rice bran, pineapple peels, brewers waste, saw dust and other waste. Microorganisms grows easily on agricultural wastes [62].

\section{SCP Production-using kefir yeast from whey}

Kefir is alcoholic beverage, prepared from raw milk and kefir grains, contains polysaccharide matrix in which bacteria and yeast symbiotically live. The origin, mood of handling and storage conditions affect microbes of beverages and kefir grain which are lactic bacteria, genera (Streptococcus and Lactobacillus) and yeast, genera (Candida, Saccharomyces, Torula).

\section{SCP production-using yeast biomass in} maize and millet

In complex media maize and millet bran were used to enhance the growth rate of microorganisms. Yeast biomass has maximum yield obtained with the help of maize, therefore it is encouraged to use maize for production of cheaper biomass. Yeast biomass are more used in culture media, drugs and feed processing [54].

\section{SCP production using from corn cob}

Microbes have ability to use organic matter as source for their growth and energy production while carbon compounds required for cell biomass synthesis, to become capable to convert inorganic nitrogen in to protein. Corn cob is a hard-lignocellulosic compound that require pre-treatment before use [63].

In conclusion, SCPs have interesting characteristics as nutrient supplement for human diet. It contains not only protein but are also rich in fats, carbohydrates, water, phosphorus and potassium. SCP can be produced all around the year, comprises high protein and low-fat contents, has capability to grow on waste material and possesses environmental friendly properties. Therefore, the production of SCP is promising way to tackle protein deficiency problem worldwide particularly in developing countries. However, high nucleic acid content, undigestible cell wall, unacceptable flavors and colors and high contamination rate make it less important and demand further improvements. 


\section{Authors' contributions}

Conceived and designed the experiments: $\mathrm{H}$ Ullah \& MW Khan, Performed the experiments: A Raziq \& H Ullah, Analyzed the data: M Lateef \& A Ullah, Contributed materials/ analysis/ tools: MW Khan, Wrote the paper: H Ullah.

\section{References}

1. Pihlajaniemi V, Ellila S, Poikkimaki S, Nappa M, Rinne M, Lantto R \& Siikaaho M (2020). Comparison of pretreatments and cost-optimization of enzymatic hydrolysis for production of single cell protein from grass silage fibre. Bioresour Technol 9: 100357.

2. Suman G, Nupur M, Anuradha $S$ \& Pradeep (2015). Single cell protein production: a review. Int $J$ Curr Microbiol App Sci 4(9): 251-262.

3. Reihani S \& Khosravi K (2019). Influencing factors on single-cell protein production by submerged fermentation: A review. Electronic J Biotechn 37: 3440.

4. Srividya AR, Vishnuvarthan VJ, Murugappan M \& Dahake PG (2013). Single Cell Protein - A Review. IJPRS 2(4): 472-485.

5. Ali Suman G, Nupur M, Anuradha S \& Pradeep B (2015). Single cell protein production: a review. Int $J$ Curr Microbiol App Sci 4(9): 251-262.

6. Zhou M, Chen P, Guo S, Shen Y, Yan P \& Yang X (2019). Recycling of orange waste for single cell protein production and the synergistic and antagonistic effects on production quality. J Clean Prod 213: 384-392.

7. Nagare B, Bhambere S, Kumar S, Kakad K \& Nagare N (2015). In Situ Gelling System: Smart Carriers for Ophthalmic Drug Delivery. IJPRS 4(1-2): 10-23.

8. Parajó JC, Santos V, Dominguez H \& Vázquez M (2010). NH 4 OH-Based pretreatment for improving the nutritional quality of single-cell protein
(SCP). Appl Biochem Biotech 55(2): 133-149.

9. Ukaegbu-Obi KM (2016). Single cell protein: a resort to global protein challenge and waste management. $J$ Microbiol Microb Technol 1(1): 5.

10. Katie B, You L \& Arnold FH (2008). Engineering microbial consortia: a new frontier in synthetic biology. Trends Biotechnol 26(9): 483-489.

11. Israelidis CJ (2015). Nutrition-Single cell protein, twenty years later. In Proceedings from First Bio international Conference.

12. Nasseri A, Rasoul-Amini S, Morowvat M \& Ghasemi Y (2011). Single cell protein: production and process. Am J Food Technol 6(2): 103-116.

13. Garimella S, Kugle K, Kssoju A \& Merugu R (2017). Current status on single cell protein (SCP) production from photosynthetic purple non sulfur bacteria. J Chem Pharma Sci 10: 915922.

14. Nasseri AT, Rasoul-Amini S, Morowvat MH \& Ghasemi Y (2011). Single cell protein: production and process. Am $J$ Food Technol 6(2): 103-116.

15. Taran M \& Asadi N (2014). A novel approach for environmentally friendly production of single cell protein from petrochemical wastewater using a halophilic microorganism in different conditions. Petrol Sci Technol 32(5): 625-630.

16. Øverland M, Tauson AH, Shearer K \& Skrede A (2010). Evaluation of methane-utilising bacteria products as feed ingredients for monogastric animals. Arch Anim Nutr 64(3): 171-189.

17. Kurbanoglu EB \& Algur OF (2002). Single-cell protein production from ram horn hydrolysate by bacteria. Bioresource Technol 85(2): 125-129.

18. Yazdian F, Hajizadeh S, Shojaosadati SA, Khalilzadeh R, Jahanshahi M \& 
Nosrati M (2005). Production of single cell protein from natural gas: Parameter optimization and RNA evaluation. Iranian J Biotech 3: 235-242.

19. Kornochalert N, Kantachote D, Chaiprapat S \& Techkarnjanaruk S (2014). Use of Rhodopseudomonas palustris P1 stimulated growth by fermented pineapple extract to treat latex rubber sheet wastewater to obtain single cell protein. Ann Microbiol 64(3): 10211032.

20. Wang JP, Kim JD, Kim JE \& Kim IH (2013). Amino acid digestibility of single cell protein from Corynebacterium ammoniagenes in growing pigs. Anim Feed Sci Tech 180(1-4): 111-114.

21. Lee JZ, Logan A, Terry S \& Spear JR (2015). Microbial response to single-cell protein production and brewery wastewater treatment. Microb Biotechnol 8: 65-76.

22. Liu B, Song J, Li Y, Niu J, Wang Z \& Yang Q (2013). Towards industrially feasible treatment of potato starch processing waste by mixed cultures. Appl Biochem Biotech 171(4): 10011010.

23. Kunasundari B, Murugaiyah V, Kaur G, Maurer FHJ \& Kumar S (2013). Revisiting the single cell protein application of Cupriavidus necator H16 and recovering bioplastic granules simultaneously. PLoS ONE 8: e78528

24. Liu B, Li Y, Song J, Zhang L, Dong J \& Yang Q (2014). Production of single-cell protein with two-step fermentation for treatment of potato starch processing waste. Cellulose 21: 3637-3645.

25. Wongputtisin $\mathrm{P}$, Khanongnuch $\mathrm{C}$, Kongbuntad W, Niamsup P, Lumyong S \& Sarkar PK (2014). Use of Bacillus subtilis isolates from Tuanao towards nutritional improvement of soya bean hull for monogastric feed application. Lett Appl Microbiol 59(3): 328-333.

26. Putri D, Ulhidayati A, Musthofa IA \& Wardani AK (2018). Single cell protein production of Chlorella sp. using food processing waste as a cultivation medium. Earth Env Sci 131(1): 012052.

27. Ardestani F \& Alishahi F (2015). Optimization of single cell protein production by Aspergillus niger using Taguchi approach. J Food Bio Sci Technol 5(2): 73-79.

28. Rhishipal R \& Philip R (1998). Selection of marine yeasts for the generation of single cell protein from prawn-shell waste. Bioresource Technol 65(3): 255256.

29. Ahmadi AR, Ghoorchian H, Hajihosaini R \& Khanifar J (2010). Detremination of the amount of protein and amino acids extracted from the microbial protein (SCP) of lignocellulosic wastes. PJBS 13(8): 355-361.

30. Aggelopoulos T, Katsieris K, Bekatorou A, Pandey A, Banat IM, \& Koutinas (2014). Solid state fermentation of food waste mixtures for single cell protein, aroma volatiles and fat production. Food Chem 145: 710-716.

31. Gao Y, Ki D \& Liu Y (2012). Production of single cell protein from soy molasses using Candida tropicalis. Ann Microbiol 62(3): 1165-1172.

32. Paraskevopoulou A, Athanasiadis I, Kanellaki M, Bekatourou A, Blekas G \& Kiosseoglou V (2003). Functional properties of single cell protein produced by kefir microflora. Food Res Int 36(5): 431-438.

33. Cui W, Wang Q, Zhang F, Zhang SC, Chi ZM \& Madzak C (2011). Direct conversion of inulin into single cell protein by the engineered Yarrowia lipolytica carrying inulinase gene. Process Biochem 46(7): 1442-1448. 
34. Zinjarde S (2014). Food-related applications of Yarrowia lipolytica. Food Chem 152: 1-10

35. Chiou PWS, Chiu SW \& Chen CR (2001). Value of Aspergillus niger fermentation product as a dietary ingredient for broiler chickens. Anim Feed Sci Tech 91(3-4): 171-182.

36. Kam S, Abedian Kenari A \& Younesi H (2012). Production of single cell protein in stickwater by Lactobacillus acidophilus and Aspergillus niger. $J$ Aquat Food Prod T 21(5): 403-417.

37. Hashem M, Hesham AEL, Alamri SA \& Alrumman SA (2014). Production of single-cell protein from wasted date fruits by Hanseniaspora uvarum KKUY0084 and Zygosaccharomyces rouxii KKUY-0157. Ann Microbiol 64(4): 1505-1511.

38. Yadav JSS, Bezawada J, Ajila CM, Yan S, Tyagi RD \& Surampalli RY (2014). Mixed culture of Kluyveromyces marxianus and Candida krusei for singlecell protein production and organic load removal from whey. Bioresource Technol 164: 119-127.

39. Jalasutram V, Kataram S, Gandu B \& Anupoju GR (2013). Single cell protein production from digested and undigested poultry litter by Candida utilis: optimization of process parameters using response surface methodology. Clean Technol Env Pol 15(2): 265-273.

40. Wiebe M (2002). Myco-protein from Fusarium venenatum: a well-established product for human consumption. Appl Microbiol Biot 58(4): 421-427.

41. Yadav JSS, Yan S, Ajila CM, Bezawada J, Tyagi RD \& Surampalli RY (2016). Food-grade single-cell protein production, characterization and ultrafiltration recovery of residual fermented whey proteins from whey. Food Bioprod Process 99: 156-165.
42. Rodriguez J, Ferraz A, Nogueira RFP, Ferrer I, Esposito E \& Duran N (1997). Lignin biodegradation by the ascomycete Chrysondia sitophila. Appl Biochem Biotech 62(2-3): 233.

43. Sisman T, Özlem G, Dogan N, Özdal M, Algur ÖF \& Ergon T (2013). Single-cell protein as an alternative food for zebrafish, Danio rerio: a toxicological assessment. Toxicol Ind Health 29(9): 792-799.

44. De Gregorio A, Mandalari G, Arena N, Nucita F, Tripodo MM \& Lo Curto RB (2002). SCP and crude pectinase production by slurry-state fermentation of lemon pulps. Bioresource Technol 83(2): 89-94.

45. Pessoa AJR, Mancilha IM \& Sato S (1996). Cultivation of Candida tropicalis in sugar cane hemicellulosic hydrolyzate for microbial protein production. $J$ Biotechnol 51(1): 83-88.

46. MJG V, Ganado LS \& Undan JR (2016). Single cell protein potential of endophytic fungi associated with bamboo using rice bran as substrate. AASR 7: 68-72.

47. Ravinder R, Venkateshwar Rao L \& Ravindra P (2003). Studies on Aspergillus oryzae mutants for the production of single cell proteins fromdeoiled rice bran. Food Technol Biotech 41(3): 243-246.

48. Baldensperger J, Le Mer J, Hannibal L \& Quinto PJ (1985). Solid state fermentation of banana wastes. Biotechnol Lett 7(10): 743-748.

49. Bhalla TC \& Joshi M (1994). Protein enrichment of apple pomace by coculture of cellulolytic moulds and yeasts. World J Microb Biot 10(1): 116117.

50. Wijeyaratne SC \& Jayathilake A (2000). Characteristics of two yeast strains (Candida tropicalis) isolated from Caryota urens (Kithul) toddy for single 
cell protein production. J Natl Sci Found Sri 28(1): 79-86.

51. Adedayo MR, Ajiboye EA, Akintunde JK, \& Odaibo A (2011). Single cell proteins: as nutritional enhancer. AASR 2(5): 396-409.

52. Ugalde U \& Castrillo S (2002). Single cell proteins from fungi and yeasts, in Applied mycology and biotechnology. Elsevier 2002(2):123-149.

53. Bekatorou A, Psarianos C \& Koutinas AA (2006). Production of food grade yeasts. Food Technol Biotech 44(3): 407-415.

54. Malav A, Meena S, Sharma M, Sharma M \& Dub P (2017). A critical review on single cell protein production using different substrates. Int J Dev Res 7(11): 16682-16687.

55. Aggelopoulos T, Katsieris K, Bekatorou A, Pandey A, Banat IM, \& Koutinas (2014). Solid state fermentation of food waste mixtures for single cell protein, aroma volatiles and fat production. Food Chem 145: 710-716.

56. Spalvins $\mathrm{K}$, Ivanovs $\mathrm{K} \&$ Blumberga $\mathrm{D}$ (2018). Single cell protein production from waste biomass: review of various agricultural by-products. Agronom Res 16(S2): 1493-1508.

57. Singhania RR, Sukumaran RK, Patel AK, Larroche C \& Pandey A (2010). Advancement and comparative profiles in the production technologies using solid-state and submerged fermentation for microbial celluloses. Enzyme Microb Tech 46(7): 541-549.

58. Deibel JR, Martin R, Ronald R, Hiebsch and Ronald DK (1988). Secreted amylolytic enzymes from Schwanniomyces occidentalis: purification by fast protein liquid chromatography (FPLC) and preliminary haracterization. Prep Biochem 18(1): 77-120.

59. Wongputtisin $\mathrm{P}$, Khanongnuch $\mathrm{C}$, Pongpiachan P \& Lumyong S (2007). Antioxidant activity improvement of soybean meal by microbial fermentation. Res J Microbiol 2(7): 577-583.

60. Callihan Clayton D \& Clemmer JE. (1979) Biomass from cellulosic materials. Microb Biom Microbiol 4: 271-88.

61. Al-Mhanna \& Najah (2011). Single Cell Protein (SCP) Production from Date Juice. Friedrich-Alexander-Universität Erlangen-Nürnberg (FAU).

62. Ravindra P (2000). Value-added food: Single cell protein. Biotechnol $A d v$ 18(6): 459-479.

63. Velmurugan $\mathrm{P}$, Hur H, Balachandar V, Kamala-Kannan S, Lee KJ, Lee SM, Chae JC, Shea PJ \& Oh BT (2011). Monascus pigment production by solidstate fermentation with corn cob substrate. J Biosci Bioeng 112(6): 590594. 